\title{
Nonmelanoma bőrtumorok kezelési lehetőségei szervtranszplantált betegeknél egy esetismertetés kapcsán
}

\author{
Gellén Emese dr. ${ }^{1}$ - Péter Zoltán dr. ${ }^{1}$ - Emri Gabriella dr. ${ }^{1}$ \\ Asztalos László dr. ${ }^{2}$. Remenyik Éva dr. ${ }^{1}$ \\ ${ }^{1}$ Debreceni Egyetem, Általános Orvostudományi Kar, Bőrgyógyászati Tanszék, Debrecen \\ ${ }^{2}$ Debreceni Egyetem, Általános Orvostudományi Kar, \\ Sebészeti Intézet, Szervtranszplantációs Nem Önálló Tanszék, Debrecen
}

\begin{abstract}
A szerzők egy 59 éves férfi esetét mutatják be, akinél először 1983-ban, majd 2000-ben végeztek vesetranszplantációt. Az első veseátültetést követően két évvel jelent meg az első laphámsejtes carcinoma a bőrön, majd 2003-tól évente legalább kettő praecancerosus laesio vagy nonmelanoma bő́rdaganat sebészeti eltávolítása történt. Ezek a tumorok elsősorban a napfénynek kitett bőrterületeken jelentek meg, multiplexen. Tekintettel arra, hogy agresszív viselkedésúek lehetnek és recidívára hajlamosak, komplex kezelést alkalmaztak a betegnél, amely magába foglalta az immunszuppresszió során alkalmazott gyógyszerek megváltoztatását, illetve mezőterápiák alkalmazását. Az eset bemutatása kapcsán a szerzők áttekintik ezeket a kezelési lehetőségeket, hangsúlyozva, hogy nemcsak a bőrdaganatok minél korábbi felismerése és aktív kezelése szükséges, hanem a betegek megfelelő fényvédelemre való oktatása és bőrgyógyászati gondozása is a bőrtumorok kialakulásának megelőzése érdekében. Orv. Hetil., 2016, 157(24), 971976.
\end{abstract}

Kulcsszavak: veseátültetés, nonmelanoma bőrdaganat, immunszuppresszív terápia, mezőkarcinogenezis, mezőterápia, fotodinámiás terápia

\section{Treatment options of non-melanoma skin tumors in organ transplant recipients in relation to a case report}

The authors present the case of a 59-year-old male patient, whose first kidney transplantation was in 1983 and the second in 2000. The first squamous cell carcinoma appeared on the skin 2 years after the first transplantation. Since 2003, at least two precancerous lesions or non-melanoma skin tumors have been removed surgically yearly. These cancers appeared predominantly on the sun-exposed skin, and were multiple. As these tumors could behave aggressively and prone to recurrence, complex treatment was applied, which included a switch in immunosuppressive drugs and the application of field therapies. The authors give an overview of these treatment options in relation to the case presentation, emphasizing that not only early detection and active treatment of the precancerous lesions and skin cancers are essential, but education of proper sun-protection methods and dermatology care are also important in order to avoid the development of these tumors.

Keywords: kidney transplantation, non-melanoma skin cancer, immunosuppressive drugs, field cancerization, field therapy, photodynamic therapy

Gellén, E., Péter, Z., Emri, G., Asztalos, L., Remenyik, É. [Treatment options of non-melanoma skin tumors in organ transplant recipients in relation to a case report]. Orv. Hetil., 2016, 157(24), 971-976.

(Beérkezett: 2016. április 6.; elfogadva: 2016. április 28.) 


\section{Rövidítések}

$\mathrm{BCC}=$ bazálsejtes carcinoma; HPV = humán papillomavírus; $\mathrm{NMSC}=$ nonmelanoma bőrdaganat; $\mathrm{PDT}=$ fotodinámiás terá pia; SCC = laphámsejtes carcinoma

A szervtranszplantációt követően kialakuló különböző daganatok incidenciája fokozatosan emelkedik a krónikus immunszuppresszió és az egyre idősebb életkor következményeként [1, 2]. Egy magyarországi szervtranszplantált populációban történt felmérés alapján a leggyakoribb tumorok körükben a börtumorok, amelyeket a vesesejtes carcinoma, lymphoma, tüdődaganat, colorectalis daganatok, emlőcarcinoma, Kaposi-szarkóma és hepatocellularis carcinoma, malignus melanoma, valamint a pajzsmirigy-carcinoma követ $[2,3]$. A poszttranszplantációs lymphomák rizikója 20-120-szoros az immunkompetens populációhoz képest [4]. A bőrtumorok kialakulásának esélye is, ahogy az előzőekben már említésre került, a szervtranszplantált betegekben az azonos korú átlagpopulációnál tapasztaltnak a többszöröse [5-7]. Leginkább a nonmelanoma bőrdaganatok (NMSC) közé tartozó laphámsejtes carcinoma (SCC) és bazálsejtes carcinoma (BCC) megjelenésének rizikója fokozódik, az előbbi vonatkozásában legalább 65-ször, az utóbbit tekintve 10-szer nagyobb az esély a kialakulásra az átlaghoz képest [7]. Emellett a malignus melanoma (3-4-szer), a Merkel-sejtes carcinoma (5-10-szer) és a Kaposi-szarkóma (84-szer) is nagyobb eséllyel jelenik meg [5]. Malignus melanoma nemcsak a bőrön, hanem a vesében is kialakulhat de novo, amelyet egy magyarországi esetismertetés kapcsán közöltek [8]. Megemelkedett az úgynevezett basosquamocellularis carcinomák előfordulása is a szervtranszplantált populációban [9]. A praecancerosus laesiók közé tartozó aktinikus keratosisok és cornu cutaneum mellett a keratoacanthomák számának növekedésére is számíthatunk [10]. Ezek a bőrdaganatok elsősorban a napfénynek kitett börterületeken, leggyakrabban a fej-nyaki régióban, kézhátakon, alkarok feszítőfelszínén, a mellkasi „V-kivágásban” jelennek meg, gyakran multiplex előfordulásúak, a field karcinogenezis részjelenségeként $[11,12]$. Kialakulásuk hátterében összetett, a fotokarcinogenezisben szerepet játszó mechanizmusok állnak. A szervtranszplantáció során és az azt követően alkalmazott immunszuppresszív szerek, leginkább az azathioprin, cyclosporin A és a tacrolimus, valószínúleg direkt módon is részt vesznek a karcinogenezis folyamatában $[5,6,12-15]$. Továbbá, a humán papillomavírus (HPV) -5, -8, -9, - 15 típusok E6/7 onkoproteinjeit mutatták ki aktinikus keratosisban, illetve laphámsejtes carcinomában, ami alapján feltételezik, hogy a HPV-vírusoknak is szerepük lehet a laesiók kialakulásában $[10,16]$. A napfény-expozíció mértékének, a világos bőrtípusnak, a p53-génmutációk jelenlétének, a transzplantáció típusának és az azóta eltelt időnek, az immunszuppresszió típusának és az alacsony CD4-sejtszámnak egyaránt jelentősége van abban, hogy mikor és milyen valószínúséggel várható bőrdaganat megjelenése egy szervtranszplantált betegnél $[5,6,9,12]$.

A bőrtumorok az átlaghoz képest agresszívebben is viselkedhetnek ezeknél a betegeknél, magasabb a lokális recidívák aránya, nagyobb számban jelenik meg áttét, így a mortalitás is magasabb [10].

A bőrdaganatok kialakulásának megelőzése érdekében nagyon fontos a primer prevenció, ennek keretén belül már a transzplantáció előtt a rizikótényezők felmérése, a betegoktatás, amelynek magában kell foglalnia a megfelelő fényvédelemre való edukációt és az önvizsgálat megtanítását is [17-21].

A praecancerosisok és nonmelanoma bördaganatok gyakran multiplex előfordulásúak e betegekben, ezért a komplex ellátás a már kialakult tumorok sebészi ellátása mellett úgynevezett mezőterápiákat is magában foglal [21-25]. Idetartoznak a fotodinámiás terápia (PDT), a lokális 5-fluorouracil-, imiquimod-, 3\%-os diclophenacés ingenolmebutat-kezelések [7]. Amennyiben évente több alkalommal is szükség van a nonmelanoma bőrdaganat sebészi excisiójára és mezőterápiára, javasolt szisztémás retinoid beállítása vagy az immunszuppresszió típusának váltása, például a calcineurininhibitor átállítása mTOR-gátlóra $[6,7,16,25]$.

\section{Esetismertetés}

A szerzők egy 59 éves férfi esetét ismertetik, akinél az első cadavervese-allotranszplantáció 1983. decemberben történt Szegeden, krónikus pyelonephritis következtében kialakult krónikus veseelégtelenség miatt. Az alkalmazott immunszuppresszív szerekrôl pontos információ nem állt rendelkezésre, azonban 1985-ben már eltávolítottak laphámsejtes carcinomát a bőrról. 1998-ban krónikus rejectio miatt graftectomiát végeztek, majd 2000. decemberben sor került a második cadavervese-allotranszplantációra a debreceni Sebészeti Klinikán. Immunszuppresszióként cyclosporin A, prednisolon és mycophenolat mofetil került beállításra. A kezelés során 2009. februárban a cyclosporin A-t tacrolimusra váltották, 2011. februárban pedig a prednisolont felfüggesztették.

A beteg foglalkozását tekintve a mezőgazdaságban dolgozott, 2009-ig sem fizikai (kalap, árnyékban tartózkodás, napszemüveg, hosszú ujjú ruházat), sem kémiai fényvédelmet (fényvédő krémek) nem alkalmazott. 2003. januártól kezdve évente legalább kettő praecancerosus laesio, illetve nonmelanoma bőrtumor eltávolítására volt szükség. 2015. júliusig összesen három aktinikus keratosis, egy cornu cutaneum, négy keratoacanthoma, hat laphámsejtes carcinoma, huszonegy bazálsejtes carcinoma és nyolc basosquamocellularis carcinoma sebészi excisiója történt meg. Ezek a tumorok leggyakrabban a fej-nyaki régióban, az alkarok feszítőfelszínén, kézhátakon, a mellkason és a háton fordultak elő. A nagyszámú bőrdaganat eltávolítása ellenére a fenti lokalizációkban számos, döntően aktinikus keratosis és nonmelanoma 
bőrdaganat volt még jelen, amikor a debreceni Bőrgyógyászati Klinikán jelentkezett (1.és 2. ábra).

2013. februárban kezdődött meg az úgynevezett field karcinogenezisnek megfelelően a mezőterápiák kombinálása, valamint 2013. márciusban az immunszuppreszszió tekintetében calcineurininhibitorról (tacrolimus) a malignus daganatok kialakulása esetén szokásos mTORinhibitorra (everolimus) való átállítás. A mezőterápia részeként három alkalommal végeztünk fotodinámiás kezelést 20\%-os 5-aminolevulinsavval a bal alkaron, egy alkalommal történt a jobb alkaron 5-fluorouracil chemowrap, a mellkason és a háton izoláltan jelen lévő aktinikus keratosisokat cryotherapiával kezeltük, emellett a nonmelanoma bőrdaganatok eltávolítása sebészi excisióval történt. Az mTOR-inhibitorra történt átállítás és az előzőekben részletezett aktív kezelések eredményeként az újonnan megjelenő aktinikus keratosisok és nonmelanoma bőrdaganatok száma jelentősen csökkent, sőt a meglévő bőrdaganatok visszafejlődését tapasztaltuk (35. ábra). Az mTOR-inhibitor mellékhatásaként kezdetben a szájnyálkahártyán fájdalmas aphthosus fekélyek alakultak ki, amelyek lokális konzervatív terápia mellett gyógyultak. A későbbiekben a sebgyógyulás elhúzódását, a nonmelanoma bőrdaganatok mútéti helyeinél a félvastag bőrgraftok elhalását tapasztaltuk.

A beteg végül 2015. októberben, bal oldali csípőprotézis-mütétet követően kialakuló nem gyógyuló mütéti terület, majd szepszis következtében létrejött többszervi elégtelenség miatt elhunyt.

\section{Megbeszélés}

A szervtranszplantált populációban a különböző de novo daganatok incidenciája emelkedő tendenciát mutat [ 1 , 26]. Ez második helyen áll a cardiovascularis események miatt létrejött elhalálozást követően $[1,8]$. Kialakulásuk hátterében nagyrészt a krónikus immunszuppresszió feltételezhető, ezért elsősorban azoknak a daganatoknak a kialakulási esélye emelkedett, amelyeknek patogenezisében onkogén vírusokat feltételeznek $[2,27]$. Egy magyarországi szervátültetett populációban, 40 éves viszonylatban, felmérték a poszttranszplantációs daganatok arányát, amelyek közül a leggyakoribbak a bőrdaganatok, a vesesejtes carcinoma és a tüdődaganat voltak. A vizsgált 40 évben a betegek átlagéletkora 35,7 évről 56,5 évre emelkedett, valamint az 50 és 60 év felett transzplantált betegek aránya is jelentősen nőtt [1].

A szervtranszplantált betegeknél a bőrdaganatok közül elsősorban a nonmelanoma bőrdaganatok kialakulásának esélye emelkedett több mint tízszeresre az immunkompetens populációhoz viszonyítva [10-12]. A férfi nem, az idősebb életkor, a világos bőrtípus, a transzplantáció óta eltelt hosszabb idő, a rendszeres napfény-expozíció, azathioprin, cyclosporin A vagy tacrolimus immunszuppresszív kezelés mind prediszponáló tényezók az NMSC-k kialakulása szempontjából [16, 17, 19, 20, 24]. Ráadásul a bőrdaganattal diagnosztizált szerv- transzplantált betegek 25\%-ánál 13 hónapon belül egy újabb bőrdaganat megjelenése várható, továbbá a laphámsejtes carcinomából kiinduló áttétek incidenciája ezeknél a betegeknél 5-7\%-ra tehető [21]. Mindez alátámasztja a bőrgyógyászati onkológiai gondozás jelentőségét, valamint a nonmelanoma bőrtumorokra vonatkozó primer, szekunder és tercier prevenció javításának szükségességét a szervtranszplantáltaknál [15].

A primer prevenció részeként fontos lenne már a transzplantáció előtt a betegek egyéni rizikófaktorainak felmérése, bőrük vizsgálata, figyelmük felhívása és oktatásuk a megfelelő fényvédelmi módszerek alkalmazására és a havonkénti rendszeres önvizsgálatra $[17,22,28$, 29]. Az egyéni rizikófaktoroktól függően a transzplantált betegek 3, 6, 12 havonkénti bőrgyógyászati vizsgálata lenne indokolt $[25,29]$.

A nonmelanoma bőrdaganatok elsősorban a napfénynek kitett bőrterületeken, a hajjal nem fedett fejbőrön, az arcon, fülön, a mellkas $\mathrm{V}$-jében a ruhakivágásnak megfelelően, a háton, kézhátakon, alkarok feszítőfelszínén jelennek meg, sokszor multiplex előfordulásúak a field karcinogenezis következményeként [16, 17]. Eszerint egy régióban gyakran több praecancerosis észlelhető, például aktinikus keratosis, a már definitív laphámsejtes carcinoma mellett, de ezek is csak mintegy a jéghegy csúcsaiként, ugyanis a látható laesiók körül a még épnek tûnő környező bőr keratinocytái már nagy valószínúséggel szintén tartalmaznak bizonyos fokú DNS-károsodást, aminek talaján előbb vagy utóbb malignus folyamat fog elindulni. Ez a field karcinogenezis lényege, ami miatt nem elég csak a már kialakult bőrdaganat eltávolítása, hanem az egész napfénykárosodott bőrterületet komplexen szükséges kezelni [30, 31].

Erre alkalmasak a mezőterápiák, a fotodinámiás terápia, a lokális 5-fluorouracil, imiquimod, 3\%-os diclophenac, ingenol mebutat $[7,21-23,25]$, amelyekkel egy adott régióban a praecancerosus keratinocytakárosodások és laesiók, illetve felszínes incipiens nonmelanoma bőrtumorok egyszerre kezelhetők. Alkalmazásuk során mellékhatásként az adott bőrterületen hyperaemia, égő érzés, majd eróziók kialakulása várható, amelyek rövid időn belül, általában heg nélkül gyógyulnak, bár hipo-, hiperpigmentáció visszamaradhat. Magyarországon jelenleg a fotodinámiás terápia elérhető, illetve az 5\%-os imiquimod és az 5 -fluorouracil lokális készítmények kaphatók kereskedelmi forgalomban.

Az imiquimod (toll-like receptor $7 / 8$ agonista) lokális immunmodulátorként fejti ki a hatását, a graft kilökődését nem segíti elő. Két különböző koncentrációban (3,75\% és $5 \%)$ is létezik, Magyarországon az 5\%-os koncentrációjú kapható. Az 5\%-os formát aktinikus keratosisok, field karcinogenezis esetén hetente kétszer-háromszor, 16 héten át, superficialis BCC esetén hetente öt alkalommal, 6 héten keresztül javasolt alkalmazni éjszakánként [21, 22, 25]. A hatékonyságát a laesiók kifejezett gyulladása, pörkképződés kíséri. 


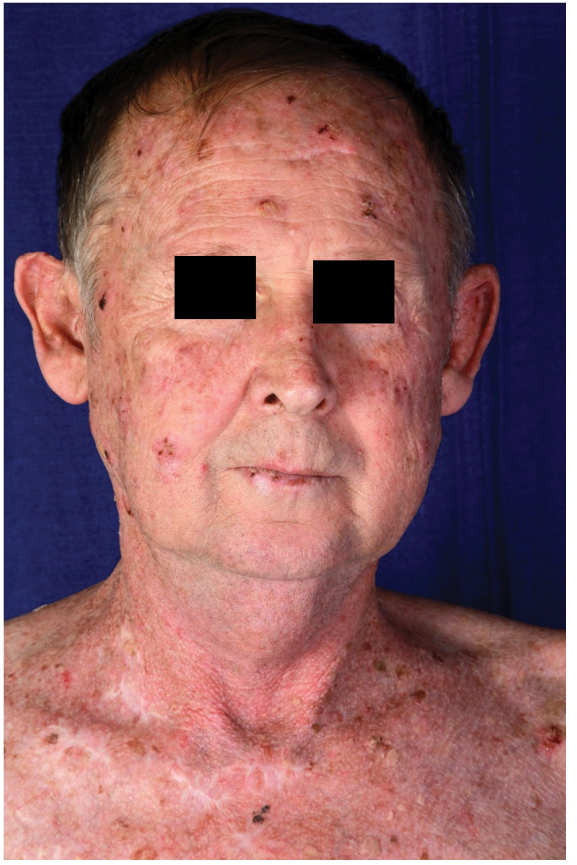

1. ábra

| Számos aktinikus keratosis, NMSC és a korábbi műtétek hegei

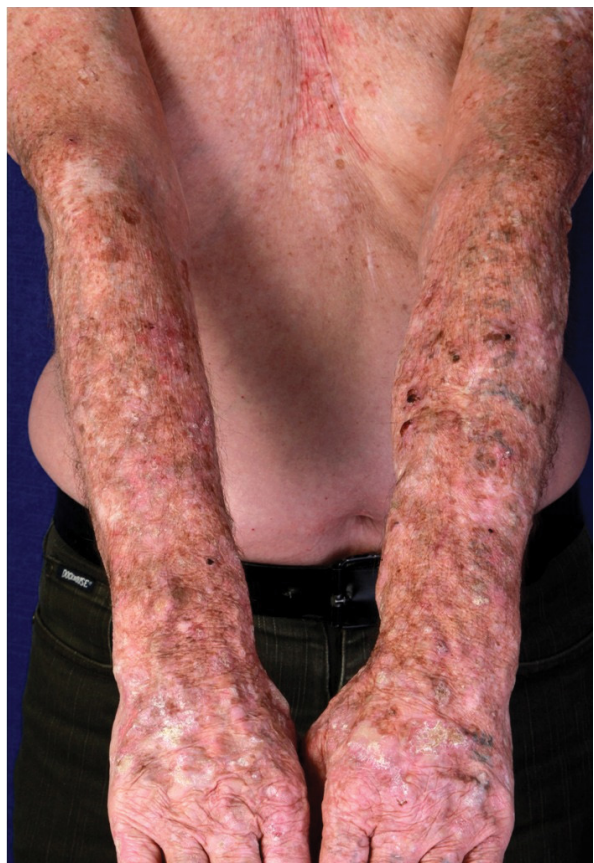

2. ábra

A napfénynek kitett és a fénytől védett bőrterületek között különbség

Az 5\%-os 5-fluorouracil a timidilát-szintetázt gátolja, aktinikus keratosis esetén naponta kétszer, 2-4 héten át, superficialis BCC esetén naponta kétszer, 3-6 héten át szükséges felvinni a laesióra [21, 22]. Kötésben, chemowrap (egész mezőre egyenletesen felvitt, egy hétig kötésben tartva) formában nagyobb hatékonyságot tud kifejteni [32].

Fotodinámiás terápia során - amely hazánkban a biztosító által nem támogatott - a fényérzékenyítő 5-ami-

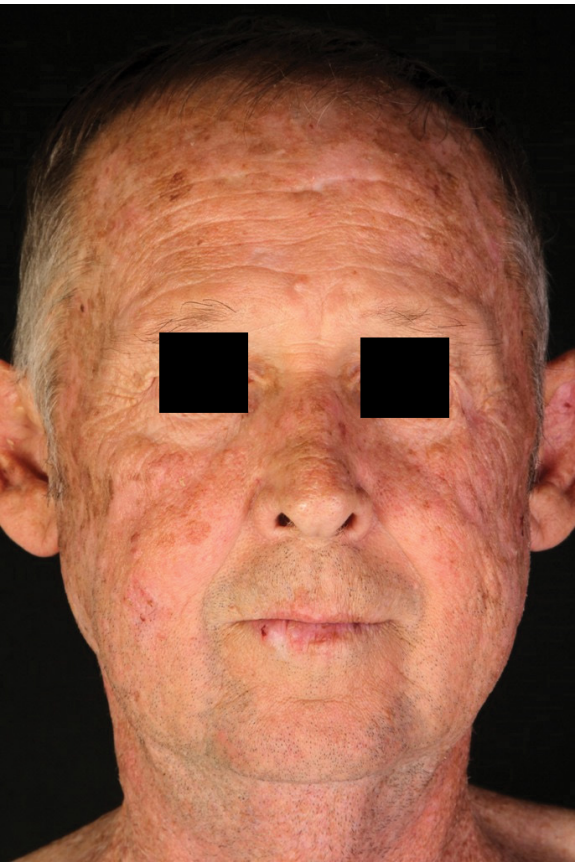

3. ábra

6 hónappal az everolimusra való átállítást és cryotherapiákat követően

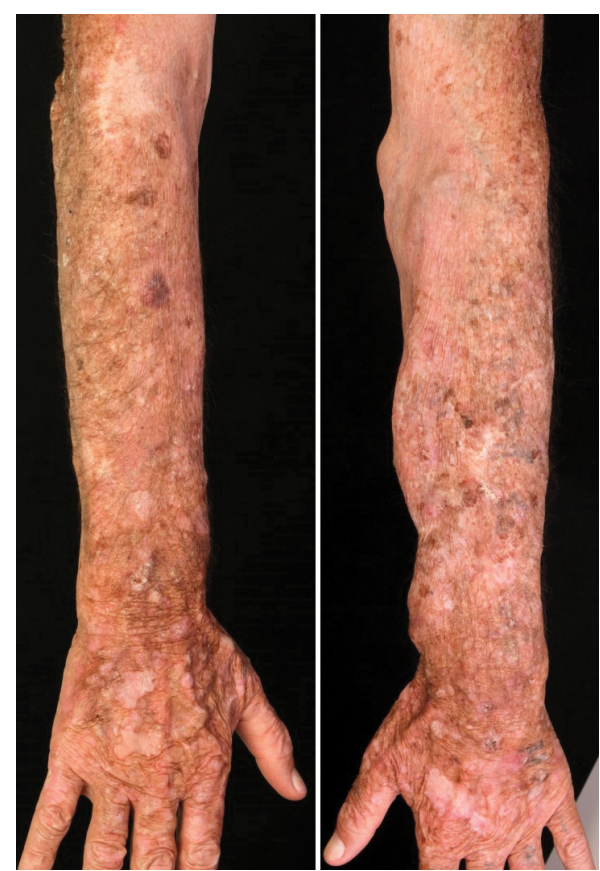

4. és 5. ábra 6 hónappal az everolimusra való átállítást, a bal alkaron a három fotodinámiás terápiát, a jobb alkaron az 5 -fluorouracil chemowrapben való alkalmazását követően

nolevulinsav lokális alkalmazását követően, az inkubációs idő elteltével, döntően vörös fénnyel történik a kezelt bőrterület megvilágítása. A fényérzékenyítő anyagot a gyorsan osztódó sejtek, elsősorban a praemalignus és malignus sejtek akkumulálják, protoporfirin IX-é alakítják át, aminek közvetítésével a megfelelő hullámhosszúságú fénnyel történő megvilágítás alatt reaktív oxigénszabadgyökök képződnek, a tumorsejtek apoptózisát és necrosisát okozva. Egyes irodalmi adatok alapján a cikli- 
kusan alkalmazott fotodinámiás terápiával a laphámsejtes carcinoma incidenciája csökkenthető $[31,33,34]$, illetve profilaktikusan alkalmazott PDT-vel az aktinikus keratosisok kialakulása késleltethető [35].

Magyarországon még nem hozzáférhető a 3\%-os diclophenac és az ingenol mebutát.

A 3\%-os diclophenacot naponta kétszer, 60-90 napon át javasolt alkalmazni. Szervtranszplantáltaknál az 5-fluorouracilhoz és az imiquimodhoz viszonyítva alacsonyabb a hatékonysága $[21,22]$.

$\mathrm{Az}$ ingenol mebutát szervtranszplantáltak esetén történő alkalmazásával kapcsolatban randomizált, kontrollált tanulmányok vannak folyamatban.

Különálló aktinikus keratosisok cryotherapiával, ablatív lézerrel, illetve elektrokoagulációval is kezelhetók [22, 23, 25], a kezelés mellékhatásaként kialakuló pigmentációs eltérés megmaradhat.

Magas rizikójú laphámsejtes és bazálsejtes carcinoma esetén elsőként választandó kezelési mód a sebészi excisio, lehetőség szerint Mohs-féle mikroszkopikusan kontrollált módszer szerint [23, 25]. Magas rizikójú SCC-nél a sentinelnyirokcsomó-biopsziát és adjuváns radioterápiát is fontolóra kell venni $[23,25]$.

Metasztatikus laphámsejtes carcinoma esetén capecitabin (5-fluorouracil prodrug) vagy EGFR-gátló cetuximabkezelés próbálható $[22,25]$. Néhány közleményben a capecitabin laphámsejtes carcinoma incidenciáját csökkentő hatásáról is beszámoltak [22, 25].

Azoknál a betegeknél, akiknél évente legalább öt magas rizikójú laphámsejtes carcinoma eltávolítása szükséges, az immunszuppressziót a lehető legalacsonyabb szintre ajánlott csökkenteni, vagy stabil graftfunkció esetén a calcineurininhibitor mTOR-gátlóra való átállítása, illetve szisztémás retinoid beállítása javasolt $[6,7,16$, $24,25,36]$. Három nagyobb tanulmányban is vizsgálták az mTOR-gátlók nonmelanoma bőrdaganat incidenciáját csökkentő hatását, amelyből kettőben (Australian skin cancer trial, TUMORAPA) az SCC-k incidenciájának csökkenéséról számoltak be, a harmadikban (RESCUE) azonban csupán az SCC-k kialakulását késleltető hatását tapasztalták [37]. Mindhárom tanulmányban két év volt a megfigyelési periódus [37]. Emellett az mTOR-gátlóra való átállítás esetén számolni kell mellékhatásokkal: a sebgyógyulás lassulásával, a szájnyálkahártyán fájdalmas aphthák megjelenésével [38].

Szisztémás retinoidok beállítása esetén is az újonnan kialakuló laphámsejtes carcinomák számának csökkenése várható. A mellékhatások (szem-, száj-, bőrszárazság, hyperlipidaemia, májenzimek emelkedése) minimalizálása céljából kezdetben alacsony dózis javasolt, amelyet fokozatosan szükséges emelni a terápiás dózis eléréséig, elhagyása esetén pedig rebound effektus várható, ami nehezen kontrollálható $[25,39]$.

Terápiás lehetőségeink áttekintése kapcsán elmondható, hogy számos kezelési módszer áll rendelkezésre a field karcinogenezis, praecancerosisok és nonmelanoma bőrtumorok megoldására, azonban a szervtranszplantál- taknál megfigyelhető agresszívebb daganatviselkedés, a lokális recidívák magas aránya és a metasztázisképzésre való fokozott hajlam miatt mégis a bőrdaganatok kialakulásának megelőzésére, a primer prevencióra kell nagyobb hangsúlyt fektetni, a betegek figyelmének felhívásával a fokozott rizikóra és a megfelelő fényvédelmi módszerek oktatásával, bőrgyógyászati gondozással. A debreceni centrumban elindult a betegek fényvédelmi és napozási szokásainak felmérése és emellett figyelmük ismételt felhívása a fokozott rizikóra, illetve oktatásuk a megfelelő fényvédelemre. Ennek során Power Point prezentációval, megfelelő napozási és fényvédelmi szokásokat ábrázoló szóróanyaggal végezzük a betegoktatást, amelyben eddig 120 beteg vett részt.

Anyagi támogatás: A szerzők a közlemény megírása kapcsán anyagi támogatásban nem részesültek.

Szerzôi munkamegosztás: G. E.: A beteg bőrgyógyászati gondozása, a kézirat megírása. P. Z.: A beteg bőrsebészeti gondozása, a kézirat áttekintése, javítása. E. G., R. E.: A kézirat áttekintése, javítása. A. L.: A betegnél vesetranszplantáció elvégzése, majd sebészeti gondozása, a kézirat áttekintése, javítása. A cikk végleges változatát a szerzők elolvasták és jóváhagyták.

Érdekeltségek: A szerzőknek nincsenek érdekeltségeik.

\section{Irodalom}

[1] Végsö, G., Tóth, A., Toronyi, É., et al.: Changes in tumor charac teristics in kidney transplanted patients over the last 40 years. Transplant. Proc., 2015, 47(7), 2198-2200.

[2] Végsó, Gy., Járay, J.: Malignant tumors following renal transplantation. [A veseátültetést követően kialakuló rosszindulatú daga natok.] Orv. Hetil., 2007, 148(45), 2115-2223. [Hungarian]

[3] Végsö, G., Toronyi, É., Hajdu, M., et al.: Renal cell carcinoma of the native kidney: a frequent tumor after kidney transplantation with favorable prognosis in case of early diagnosis. Transplant. Proc., 2011, 43(4), 1261-1263.

[4] Végsö, Gy.: Post-transplantation malignant tumors and the challenges of immunosuppressive therapy in transplanted patients developing lymphoma. Mycophenolic acid as a possibility. [A szervátültetést követő rosszindulatú daganatok problémája, különös tekintettel a lymphomában szenvedő, transzplantált betegeknél választandó immunszuppresszív kezelésre. A mycophenolsav, mint lehetőség.] Magy. Onkol., 2009, 53(2), 149-156. [Hungarian]

[5] Tufaro, A. P., Azoury, S. C., Crompton, J. G., et al.: Rising incidence and aggressive nature of cutaneous malignancies after transplantation: An update on epidemiology, risk factors, management and surveillance. Surg. Oncol., 2015, 24(4), 345-352.

[6] Tessari, G., Girolomoni, G.: Nonmelanoma skin cancer in solid organ transplant recipients: Update on epidemiology, risk factors, and management. Dermatol. Surg., 2012, 38(10), 16221630 .

[7] Brin, L., Zubair, A. S., Brewer, J. D.: Optimal management of skin cancer in immunosuppressed patients. Am. J. Clin. Dermatol., 2014, 15(4), 339-356.

[8] Nemes, B., Toronyi, É., Rajczy, K., et al.: De novo malignant melanoma occurred in renal allograft: DNA typing to determine the 
origin of the tumour. Intervent. Med. Appl. Sci., 2010, 2(1), 31-36.

[9] Mougel, F., Kanitakis, J., Faure, M., et al.: Basosquamous cell carcinoma in organ transplant patients: A clinicopathologic study. J. Am. Acad. Dermatol., 2012, 66(5), el51-el57.

[10] Zwald, F. O., Brown, M.: Skin cancer in solid organ transplant recipients: Advances in therapy and management. Part I. Epidemiology of skin cancer in solid organ transplant recipients. J. Am. Acad. Dermatol., 2011, 65(2), 253-261.

[11] Rodriguez-Acosta, E. D., Calva-Mercado, J. J., Alberu-Gómez, J., et al.: Patients with solid organ transplantation and skin cancer: determination of risk factors with emphasis in photoexposure and immunosuppressive regimen. Experience in a third level hospital. Gac. Med. Mex., 2015, 151(1), 19-24.

[12] Mudigonda, T., Levender, M. M., O'Neill, J. L., et al.: Incidence, risk factors, and preventative management of skin cancers in organ transplant recipients: A review of single- and multicenter retrospective studies from 2006 to 2010. Dermatol. Surg., 2013, $39(3 \mathrm{Pt} 1), 345-364$.

[13] Wheless, L., Jacks, S., Potter, K. A., et al.: Skin cancer in organ transplant recipients: more than the immune system. J. Am. Acad. Dermatol., 2014, 71(2), 359-365.

[14] Jung, J. W., Overgaard, N. H., Burke, M. T., et al.: Does the nature of residual immune function explain the differential risk of non-melanoma skin cancer development in immunosuppressed organ transplant recipients? Int. J. Cancer, 2015, 138(2), 281292.

[15] Kuschal, C., Thoms, K. M., Schubert, S., et al.: Skin cancer in organ transplant recipients: effects of immunosuppressive medications on DNA repair. Exp. Dermatol., 2012, 21(1), 2-6.

[16] Chockalingam, R., Downing, C., Tyring, S. K.: Cutaneous squamous cell carcinomas in organ transplant recipients. J. Clin. Med., 2015, 4(6), 1229-1239.

[17] Feuerstein, I., Geller, A. C.: Skin cancer education in transplant recipients. Prog. Transplant., 2008, 18(4), 232-242.

[18] Francis, S., Berg, D.: Reducing skin malignancy risk in organ transplant recipients. Skin Ther. Lett., 2013, 18(1), 1-3.

[19] Terhorst, D., Drecoll, U., Stockfleth, E., et al.: Organ transplant recipients and skin cancer: assessment of risk factors with focus on sun exposure. Br. J. Dermatol., 2009, 161(Suppl. 3), 85-89.

[20] Moloney, F. J., Almarzouqi, E., O'Kelly, P., et al.: Sunscreen use before and after transplantation and assessment of risk factors associated with skin cancer development in renal transplant recipients. Arch. Dermatol., 2005, 141(8), 978-982.

[21] Bangash, H. K., Colegio, O. R.: Management of non-melanoma skin cancer in immunocompromised solid organ transplant recipients. Curr. Treat. Options Oncol., 2012, 13(3), 354-376.

[22] Ritchie, S. A., Patel, M. J., Miller, S. J.: Therapeutic options to decrease actinic keratosis and squamous cell carcinoma incidence and progression in solid organ transplant recipients: a practical approach. Dermatol. Surg., 2012, 38(10), 1604-1621.

[23] Singh, M. K., Brewer, J. D.: Current approaches to skin cancer management in organ transplant recipients. Semin. Cutan. Med. Surg., 2011, 30(1), 35-47.

[24] Ulrich, C., Arnold, R., Frei, U., et al.: Skin changes following organ transplantation. Dtsch. Arztebl. Int., 2014, 111(11), 188194.
[25] Zwald, F. O., Brown, M.: Skin cancer in solid organ transplant recipients: Advances in therapy and management. Part II. Management of skin cancer in solid organ transplant recipients. J. Am. Acad. Dermatol., 2011, 65(2), 263-279.

[26] Penn, I.: Occurrence of cancers in immunosuppressed organ transplant recipients. Clin. Transpl., 1998, 147-158.

[27] Penn, I.: Cancers in renal transplant recipients. Adv. Ren. Replace. Ther., 2000, 7(2), 147-156.

[28] Lloyd, A., Klintmalm, G., Qin, H., et al.: Skin cancer evaluation in transplant recipients: A physician opinion survey with recommendations. Clin. Transplant., 2015, 29(2), 110-117.

[29] Hofbaner, G. F., Anliker, M., Arnold, A., et al.: Swiss clinical practice guidelines for skin cancer in organ transplant recipients. Swiss Med. Wkly, 2009, 139(29-30), 407-415.

[30] Imko-Walczuk, B., Kielbowick, M., Dębska-Ślizień, A., et al.: Skin cancers as contraindication to organ transplantation. Transplant. Proc., 2015, 47(6), 1547-1552.

[31] Basset-Seguin, N., Baumann Conzett, K., Gerritsen, M. J., et al.: Photodynamic therapy for actinic keratosis in organ transplant patients. J. Eur. Acad. Dermatol. Venereol., 2013, 27(1), 57-66.

[32] Mann, M., Berk, D. R., Petersen, J.: Chemowraps as an adjuvant to surgery for patients with diffuse squamous cell carcinoma of the extremities. J. Drugs Dermatol., 2008, 7(7), 685-688.

[33] Willey, A., Mehta, S., Lee, P. K.: Reduction in the incidence of squamous cell carcinoma in solid organ transplant recipients treated with cyclic photodynamic therapy. Dermatol. Surg., 2010, 36(5), 652-658.

[34] Hasson, A., Navarrete-Dechent, C., Nicklas, C., et al.: Topical photodynamic therapy with methylaminolevulinate for the treatment of actinic keratosis and reduction of photodamage in organ transplant recipients: a case-series of 16 patients. Indian J. Dermatol. Venereol. Leprol., 2012, 78(4), 448-453.

[35] Togsverd-Bo, K., Omland, S. H., Wulf, H. C., et al.: Primary prevention of skin dysplasia in renal transplant recipients with photodynamic therapy: a randomized controlled trial. Am. J. Transplant., 2015, 15(11), 2986-2990.

[36] Kovach, B. T., Murphy, G., Otley, C. C., et al.: Oral retinoids for chemoprevention of skin cancers in organ transplant recipients: results of a survey. Transplant. Proc., 2006, 38(5), 1366-1368.

[37] Geissler, E. K.: Skin cancer in solid organ transplant recipients: are mTOR inhibitors a game changer? Transplant. Res., 2015, 4, $1-6$.

[38] Feldmeyer, L., Hofbaner, G. F., Böni, T., et al.: Mammalian target of rapamycin (mTOR) inhibitors slow skin carcinogenesis, but impair wound healing. Br. J. Dermatol., 2012, 166(2), 422-424.

[39] Chen, K., Craig, J. C., Shumack, S.: Oral retinoids for the prevention of skin cancers in solid organ transplant recipients: a systematic review of randomized controlled trials. Br. J. Dermatol., $2005,152(3), 518-523$.

(Gellén Emese dr., Debrecen, Nagyerdei krt. 98., 4032 e-mail: emesegellen@med.unideb.hu) 